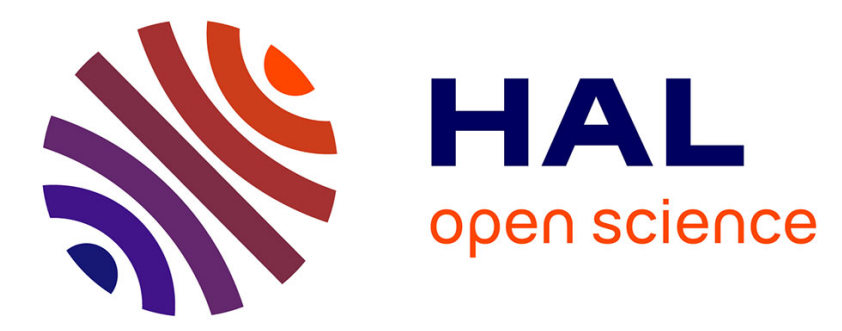

\title{
Influence of particle size, reactor temperature and gas phase reactions on fast pyrolysis of beech wood
}

Li Chen, Capucine Dupont, Sylvain Salvador, Guillaume Boissonnet, Daniel Schweich

\section{- To cite this version:}

Li Chen, Capucine Dupont, Sylvain Salvador, Guillaume Boissonnet, Daniel Schweich. Influence of particle size, reactor temperature and gas phase reactions on fast pyrolysis of beech wood. International Journal of Chemical Reactor Engineering, 2010, 8, p.1-19. 10.2202/1542-6580.1922 . hal01846914

\section{HAL Id: hal-01846914 \\ https://hal.science/hal-01846914}

Submitted on 8 Nov 2019

HAL is a multi-disciplinary open access archive for the deposit and dissemination of scientific research documents, whether they are published or not. The documents may come from teaching and research institutions in France or abroad, or from public or private research centers.
L'archive ouverte pluridisciplinaire HAL, est destinée au dépôt et à la diffusion de documents scientifiques de niveau recherche, publiés ou non, émanant des établissements d'enseignement et de recherche français ou étrangers, des laboratoires publics ou privés. 


\title{
Influence of Particle Size, Reactor Temperature and Gas Phase Reactions on Fast Pyrolysis of Beech Wood
}

\author{
Li Chen, Capucine Dupont, Sylvain Salvador, Guillaume Boissonnet, and Daniel \\ Schweich
}

\begin{abstract}
In the present work, a drop tube reactor (DTR) and a horizontal tubular reactor (HTR) were used to study the pyrolysis behaviour of beech wood particles of different sizes under the conditions encountered in industrial fluidized bed gasifiers, namely high external heat flux $\left(105-106 \mathrm{~W} \cdot \mathrm{m}^{-2}\right)$ and high temperature $(800-$ $\left.1000^{\circ} \mathrm{C}\right)$. The influence of the reactor temperature $\left(800\right.$ and $\left.950^{\circ} \mathrm{C}\right)$, of particle size (from $350 \mu \mathrm{m}$ to $6 \mathrm{~mm}$ ), and of gas residence time (from 1 to $10 \mathrm{~s}$ ) were examined. Under the explored conditions, when pyrolysis is finished, more than $80 \mathrm{wt} . \%$ of virgin wood is converted into gas and less than $13 \mathrm{wt} . \%$ remains in solid. In the gas phase, $\mathrm{CO}$ is the main gaseous product (50 wt.\% of virgin wood), followed by $\mathrm{H}_{2}$ (molar ratios of $\mathrm{H}_{2} / \mathrm{CO}$ are between 0.35 to 0.55 ), $\mathrm{H}_{2} \mathrm{O}, \mathrm{CO}_{2}$ and $\mathrm{CH}_{4}$. Species $\mathrm{C}_{2} \mathrm{H}_{2}, \mathrm{C}_{2} \mathrm{H}_{4}, \mathrm{C}_{2} \mathrm{H}_{6}$ and $\mathrm{C}_{6} \mathrm{H}_{6}$ are present in much lower amounts. The increase of temperature increases the rate of solid devolatilization and favours the cracking reactions of hydrocarbons. The increase of particle size increases the required time for completing pyrolysis. Meanwhile, the results obtained at $950^{\circ} \mathrm{C}$ show that the final products distribution at the end of pyrolysis is almost the same for the particles between 350 and $800 \mu \mathrm{m}$. The increase of the particle size from $800 \mu \mathrm{m}$ to $6 \mathrm{~mm}$ seems to have some influence on the final products distribution. The gas phase reactions mainly change the yields of light hydrocarbons and $\mathrm{H}_{2}$ : the increase of gas residence time favours the cracking reactions of hydrocarbons and thus leads to a higher $\mathrm{H}_{2}$ yield.
\end{abstract}

KEYWORDS: biomass, fast pyrolysis, drop tube reactor, horizontal tubular reactor, gas phase reactions, particle size, high temperature 


\section{Introduction}

Biomass, as a renewable $\mathrm{CO}_{2}$-neutral energy source, is widely available and increasingly used as an alternative to fossil fuel for energy supply. The thermochemical conversion of biomass to produce fuel gas (mainly $\mathrm{CO}$ and $\mathrm{H}_{2}$ ) via gasification is considered as one of the most promising processes. The fluidized bed reactor constitutes a good option for large-scale applications of biomass gasification notably due to its high heat and mass transfer efficiency. Pyrolysis is the first step in the gasification process, and is of crucial importance since during pyrolysis up to $70-90 \%$ of feed biomass can be converted into volatiles (Dupont 2006).

Biomass pyrolysis is a complex process including both physical and chemical phenomena. Some research efforts (Pyle and Zaror 1984; Chan, Kelbon et al. 1985; Simmons 1986; Peters and Bruch 2003) have been devoted to the study of the relative importance between heat transfer processes and chemical reactions during pyrolysis by using a characteristic times analysis that was initially proposed by Damköhler (1936). Recently, Dupont et al. (2007) estimated the characteristic times of these phenomena under the operating conditions encountered in fluidized bed gasifiers. Their results indicated that in the temperature range between 800 and $950^{\circ} \mathrm{C}$, the pyrolysis of wood particles smaller than $100 \mu \mathrm{m}$ was controlled by chemical reactions while the thermal regime was governing only for particles larger than $10 \mathrm{~mm}$. For particles between $100 \mu \mathrm{m}$ and $10 \mathrm{~mm}$, the pyrolysis was found to occur in a transitional regime, in which both chemical reactions and heat transfer processes should be taken into account.

A lot of researchers (for example, (Brink and Massoudi 1978; Biagini, Fantozzi et al. 2004)) have used TGA to study the intrinsic kinetic of biomass devolatilization with small particles $(\sim 100 \mu \mathrm{m})$. Attention has also been paid to the pyrolysis of large particles $(>10 \mathrm{~mm})$ in thermal regime (Gronli 1996; Lu 2006; Bellais 2007). However, only few experimental results can be found in the literature (Zanzi, Sjostrom et al. 1996; Dupont 2006; Xiu, Li et al. 2006; Couhert 2007; Lehto 2007) concerning the pyrolysis of particles between $100 \mu \mathrm{m}$ and 10 $\mathrm{mm}$, under the typical heating conditions encountered in fluidized gasifiers, namely high heat flux $\left(10^{5}-10^{6} \mathrm{~W} \cdot \mathrm{m}^{-2}\right)$ and high temperature $\left(>800^{\circ} \mathrm{C}\right)$.

For this reason, this paper deals with an experimental study on the pyrolysis behaviour of beech wood particles covering a large range of sizes (350 $\mu \mathrm{m} ; 500 \mu \mathrm{m} ; 700 \mu \mathrm{m} ; 800 \mu \mathrm{m} ; 2 \mathrm{~mm} ; 6 \mathrm{~mm}$ ) under atmospheric pressure, high external heat flux, and temperatures of 800 and $950^{\circ} \mathrm{C}$.

The experiments were performed in a drop tube reactor (DTR) with particles between 350 and $800 \mu \mathrm{m}$. For larger particles, the solid residence time is 
too limited in this reactor configuration so that a horizontal tubular reactor (HTR) was used with particles between $800 \mu \mathrm{m}$ and $6 \mathrm{~mm}$ to complete the study.

\section{Experimental section}

\subsection{Materials}

Beech wood was selected as the biomass sample in present work. The particles smaller than $1 \mathrm{~mm}$ were sieved and classified to obtain fractions of uniform particle size. The large particles were classified through their thickness (Table 1).

Table 1. Characteristics of the beech wood samples

\begin{tabular}{|c|c|}
\hline \multicolumn{2}{|c|}{ Small particles } \\
\hline Average paticle size $(\mu \mathrm{m})$ & Moisture $(\%)$ \\
\hline 350 & 6.5 \\
\hline 500 & 6.5 \\
\hline 700 & 7.2 \\
\hline 800 & 7.5 \\
\hline \multicolumn{2}{|c|}{ Large particles } \\
\hline $\begin{array}{c}\text { Particle size }(\mathrm{mm}) \\
(\text { Length } \times \text { Width } \times \text { Thickness })\end{array}$ & Moisture $(\%)$ \\
\hline $5 \times 2 \times 2$ & 10.4 \\
\hline $20 \times 10 \times 6$ & 11.8 \\
\hline
\end{tabular}

No significant differences were observed for the samples on the proximate and ultimate analysis except on moisture (see Table 1). Therefore only an average value of the analysis is given in Table 2.

Table 2. Proximate and ultimate analysis of the sample

\begin{tabular}{|c|c|c|c|c|c|c|c|}
\hline \multicolumn{3}{|c|}{$\begin{array}{l}\text { Proximate Analysis } \\
\text { (\% Mass, Dry Basis) }\end{array}$} & \multicolumn{5}{|c|}{$\begin{array}{c}\text { Ultimate Analysis } \\
\text { (\% Mass, Dry, Ash-Free Basis) }\end{array}$} \\
\hline Volatile Matter & Fixed Carbon & Ash & $\mathrm{C}$ & $\mathrm{H}$ & $\mathrm{N}$ & $\mathrm{S}$ & $\begin{array}{c}\mathrm{O} \\
\text { (by diff.) }\end{array}$ \\
\hline 85.3 & 14.3 & 0.4 & 49.2 & 6 & 0.5 & 0.02 & 44.3 \\
\hline
\end{tabular}




\subsection{Methods}

\subsubsection{Drop Tube Reactor (DTR)}

The drop tube reactor (DTR) is depicted in Figure 1. It has already been previously described in detail by Van de Steene (1999) and Commandré (2002). This facility is designed to produce external heat fluxes at particle surface higher than about $1 \times 10^{5} \mathrm{~W} \cdot \mathrm{m}^{-2}$. It consists of an alumina tube of $2000 \times 75 \mathrm{~mm}(\mathrm{~L} \times$ i.d.), inserted in a vertical electric heater made of three independent heating zones, with a total isothermal reaction zone of $1000 \mathrm{~mm}$.

Wood particles were continuously fed by a controlled weighing system and injected into the reactor with a transport $\mathrm{N}_{2}$ stream through a water-cooled feeding tube. A dispersion dome was placed at the outlet of the feeding tube to distribute the wood particles over the reactor cross section. Another $\mathrm{N}_{2}$ stream passed through a pre-heater to reach the reactor temperature and met the wood particles at the dispersion dome. A water-cooled sampling probe was inserted from the bottom of the reactor to collect solid and gas. The reaction zone length (and thus the residence time of solid and gas) could be varied by setting the sampling probe at different heights. A representative fraction (about 2/3) of the exhaust gas was sucked in the sampling probe, then passed through a char collection pot and a filter and a part of it was sent to the gas analysis system (see 2.2.3).

The flow rate of total $\mathrm{N}_{2}$ stream, the sum of the cold transport stream and the pre-heated stream, were of 18.8 and $16.5 \mathrm{~L} \cdot \mathrm{min}^{-1}$ (at STP) at 800 and $950^{\circ} \mathrm{C}$ respectively, in order to keep the same $\mathrm{N}_{2}$ velocity in the reactor. The flow rate of wood particles was of $0.5 \mathrm{~g} \cdot \mathrm{min}^{-1}$. 


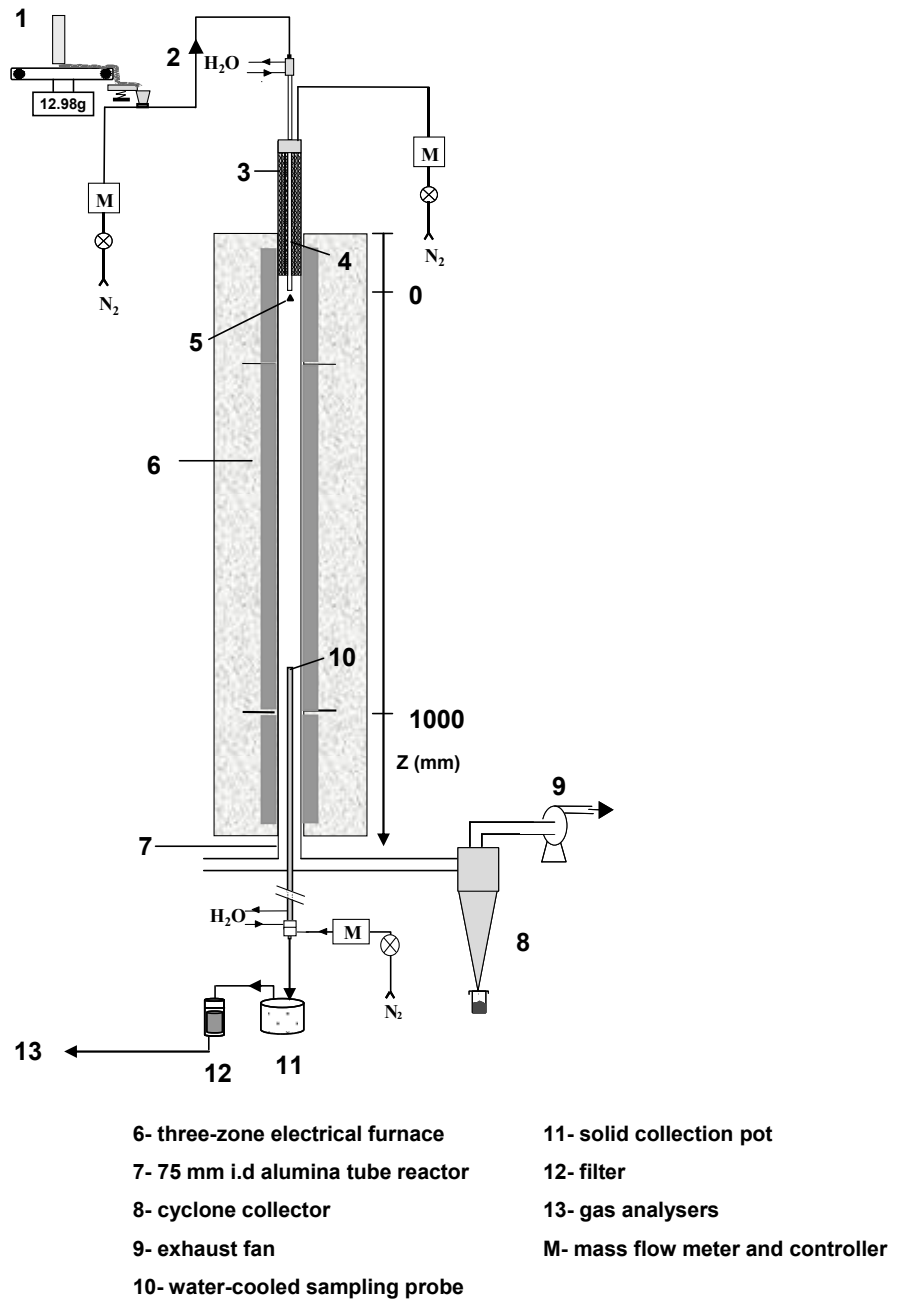

Figure 1. Scheme of the DTR

The main parameters studied in the DTR are listed in Table 3.

Table 3. Main parameters studied in the DTR

\begin{tabular}{|c|c|}
\hline Parameters & Values \\
\hline Particle size $(\mu \mathrm{m})$ & $350,500,700$ and 800 \\
\hline Temperature $\left({ }^{\circ} \mathrm{C}\right)$ & 800 and 950 \\
\hline Reaction zone length $(\mathrm{m})$ & $0.3,0.5,0.7$ and 0.9 \\
\hline
\end{tabular}


Under the explored conditions, the solid residence time was estimated to fall between 0.5 and $2.5 \mathrm{~s}$ for the sample of $350 \mu \mathrm{m}$, and between 0.3 and $0.7 \mathrm{~s}$ for the sample of $800 \mu \mathrm{m}$ (Chen, Couhert et al. 2009).

\subsubsection{Horizontal Tubular Reactor (HTR)}

The horizontal tubular reactor (HTR) is depicted in Figure 2. It has been described in detail by Couhert (2007). This facility is designed to produce external heat fluxes at particle surface up to $5 \times 10^{4} \mathrm{~W} \cdot \mathrm{m}^{-2}$ (Dufour 2007). It consists of a quartz tube heated by electrical resistances at temperatures up to $1000^{\circ} \mathrm{C}$. A double envelop configuration is used to preheat the carrier gas before meeting the solid sample. The sizes of the outer and inners tube are $1290 \times 70 \mathrm{~mm}(\mathrm{~L} \times$ i.d.) and $850 \times 55 \mathrm{~mm}(\mathrm{~L} \times$ i.d.) respectively. The heated zone has a length of $620 \mathrm{~mm}$. During the test, the isothermal gas phase reaction zone, i.e. the zone between the position of the sample holder and the end of the heated zone has a length of 320 $\mathrm{mm}$.

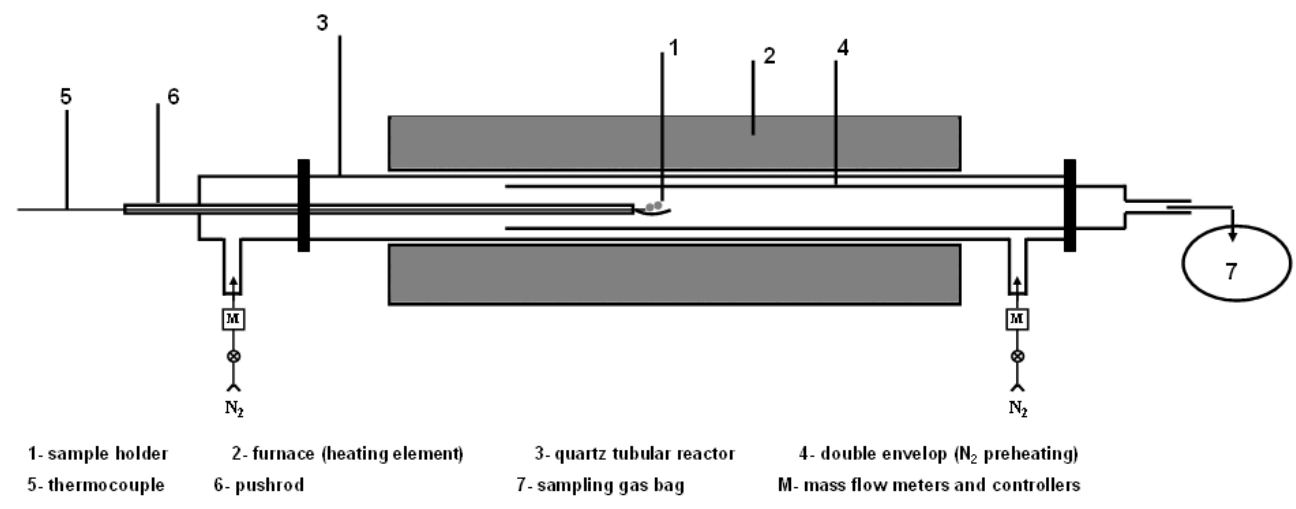

Figure 2 Scheme of HTR

Wood particles were weighed in a sample holder made of a stainless steel grid; the holder was driven by a pushrod and initially set in the cold zone of the reactor. The system was purged by $\mathrm{N}_{2} .50 \%$ of the injected $\mathrm{N}_{2}$ was preheated through the double envelope, while the other $50 \%$ of the injected $\mathrm{N}_{2}$ remained cold in order to sweep the solid particles to avoid wood devolatilization before the beginning of the test. The temperature in the cold zone was not higher than $120^{\circ} \mathrm{C}$ during this stage. During the experiments, the outlet of the reactor was firstly connected to the gas analyzers to check the oxygen concentration. Once it was ensured that no oxygen remained, the reactor outlet was connected to a sampling 
bag. The sample holder was then quickly pushed to the centre of the heated zone. At the end of the experiment, the sample holder was pulled back in the inert cold atmosphere to cool down, and then weighed. The sampling bag was connected to the gas analysis system (see 2.3.3) for the measurement of the gaseous components yields.

The solid residence time was set to $3 \mathrm{~min}$ in order to ensure that the pyrolysis was finished and that all the pyrolysis products completely left the reactor. The gas residence time in the isothermal gas phase reaction zone was controlled by the gas mass flow rate by assuming that the gas produced by pyrolysis could be negligible. The initial solid mass was of about $0.5 \mathrm{~g}$ for the sample of $800 \mu \mathrm{m}$, which was approximately placed as a monolayer of particles over the holder. It was of between 0.5 and $1 \mathrm{~g}$ for the samples of 2 and $6 \mathrm{~mm}$, which consisted in several particles that could be considered as isolated on the holder.

Note that the samples were oven-dried before being placed in the sample holder in order to avoid any moisture evaporation during the $\mathrm{N}_{2}$ purging stage before the experiment.

The main parameters studied in the HTR are listed in Table 4.

Table 4. Main parameters studied in the HTR

\begin{tabular}{|c|c|}
\hline Parameters & Values \\
\hline Particle size $(\mathrm{mm})$ & $0.8,2$ and 6 \\
\hline Temperature $\left({ }^{\circ} \mathrm{C}\right)$ & 800 and 950 \\
\hline Gas residence time $(\mathrm{s})$ & 1,4 and 11 at $800^{\circ} \mathrm{C}$ \\
& 1,3 , and 10 at $950^{\circ} \mathrm{C}$ \\
\hline
\end{tabular}

\subsubsection{Measurement}

\subsubsection{Analysis methods}

The same gas analysis system was used for all the experiments. Note that to test the influence of the sampling method (direct sampling or sampling bag), Couhert (2007) carried out in the DTR a pyrolysis test during which she measured the gas yields by direct online measurement of the sampled gas and by analyzing a sampling bag after the pyrolysis test. The results were similar, which proved that the sampling method did not affect the results.

The gas analysis system is constituted of several analyzers, as shown in Table 5. The yields of all the main gaseous components except water vapour were measured by at least two different analyzers. Note that there is a high uncertainty on the $\mathrm{H}_{2} \mathrm{O}$ value given by the mirror hygrometer due to the fact that the mirror 
surface might be contaminated by the condensed components in the released gas. Hence, the yield of water vapour may only be considered as indicative. Its uncertainty is not negligible and may represent up to $6 \%$ as mass fraction in the total produced gas.

Table 5. Gas analysis system

\begin{tabular}{|c|c|c|c|c|c|c|c|c|c|c|}
\hline & $\mathrm{H}_{2}$ & $\mathrm{CO}$ & $\mathrm{CO}_{2}$ & $\mathrm{H}_{2} \mathrm{O}$ & $\mathrm{CH}_{4}$ & $\mathrm{C}_{2} \mathrm{H}_{4}$ & $\mathrm{C}_{2} \mathrm{H}_{2}$ & $\mathrm{C}_{2} \mathrm{H}_{6}$ & $\mathrm{C}_{6} \mathrm{H}_{6}$ & $\mathrm{O}_{2}$ \\
\hline Micro GC & $\mathrm{x}$ & $\mathrm{x}$ & $\mathrm{x}$ & & $\mathrm{x}$ & $\mathrm{x}$ & $\mathrm{x}$ & $\mathrm{x}$ & $\mathrm{x}$ & \\
\hline FTIR $^{1}$ & & $\mathrm{X}$ & $\mathrm{x}$ & & $\mathrm{x}$ & $\mathrm{x}$ & $\mathrm{x}$ & $\mathrm{x}$ & & \\
\hline $\mathrm{TCD}^{2}$ & $\mathrm{X}$ & & & & & & & & & \\
\hline $\mathrm{FID}^{3}$ & & & & & $\mathrm{X}$ & & & & & \\
\hline $\mathrm{NDIR}^{4}$ & & & $\mathrm{x}$ & & & & & & & $\mathrm{x}$ \\
\hline Mirror hygrometer & & & & $\mathrm{x}$ & & & & & & \\
\hline $\begin{array}{l}\text { Relative } \\
\text { uncertainty }( \pm \%)\end{array}$ & 10 & 5 & 10 & $\begin{array}{c}20- \\
50\end{array}$ & 10 & 20 & 10 & 20 & 20 & 10 \\
\hline
\end{tabular}

1. Fourier Transform InfraRed spectrometer

2. Thermal Conductivity Detector

3. Flame Ionization Detector

4. Non-Dispersive InfraRed spectrometer

The methods for determining the solid mass loss were different for the experiments in the DTR and those in the HTR.

- the mass loss of solid pyrolyzed in the DTR was determined by the ash tracer method, the most common method used to determine the solid mass loss in the DTR (for example, see (Zanzi, Sjöström et al. 1996; Li, Xu et al. 2004; Xiu, Li et al. 2006)).

- the mass loss of solid pyrolyzed in the HTR was determined by directly weighing the sample before and after pyrolysis test.

Due to the lack of direct measurement, the tar yield was considered as equal to the difference between the virgin wood and the sum of the yields of gas and solid residue. Under the explored conditions, the tar yield may represent up to $10-15$ wt.\% of the initial wood at the end of pyrolysis, as explained in (Dupont 2006).

\subsubsection{Repeatability}

The result repeatability was checked by performing the same test on three different days.

- For the yields of gaseous components, it was found that for the experiments conducted in both reactors, the relative differences of results on each gaseous 
component among these three tests was below 5\% except for $\mathrm{H}_{2} \mathrm{O}$ in which case it was of about $20 \%$. This indicates that the experimental results were reliable.

- For the yields of solid, it was found that for the experiments conducted in the DTR, the relative differences of solid mass losses obtained among these three tests were up to $20 \%$. This was mainly due to the small ash content in the virgin wood (about $0.3 \mathrm{wt} . \%$ ). On the contrary, for the experiments in HTR, the relative differences of solid mass losses obtained among three tests were less than 5\%. This indicates that the solid mass loss in the HTR was accurately determined.

\section{Results and discussion}

\subsection{Results obtained in the DTR}

\subsubsection{Final products distribution}

This paragraph aims to compare the results obtained in the present study with those reported by the former authors concerning the experiments conducted under similar operating conditions. Since only for the sample of $350 \mu \mathrm{m}$, the pyrolysis is finished under all the studied operating conditions (see Figure 3), the results of the sample of $350 \mu \mathrm{m}$ are used to compare with literature results.

First of all, the comparison of final solid/gas/tar yields at $800^{\circ} \mathrm{C}$ is presented in Table 6.

Table 6. Comparison of final solid/gas/tar yields at $800^{\circ} \mathrm{C}$ with literature results

\begin{tabular}{|c|c|c|c|c|}
\hline & Present study & $\begin{array}{c}\text { (Dupont, } \\
\text { Commandré et } \\
\text { al. 2008) }\end{array}$ & $\begin{array}{c}\text { (Zhang, Kajitani } \\
\text { et al. 2006) }\end{array}$ & $\begin{array}{c}\text { (Zanzi, } \\
\text { Sjöström et } \\
\text { al. 2002) }\end{array}$ \\
\hline Sample & Beech wood & $\begin{array}{c}\text { Mixture of } \\
\text { pine and spruce }\end{array}$ & Cypress sawdust & Birch wood \\
\hline Particle size $(\mu \mathrm{m})$ & 336 & 400 & $<500$ & $500-800$ \\
\hline Solid yield $(w t . \%)$ & 6 & $7-10$ & 5 & 6 \\
\hline Gas yield $(w t . \%)$ & 83 & 75 & 85 & 77 \\
\hline Tar yield $(w t . \%)$ & 11 & $15-18$ & 10 & 18 \\
\hline
\end{tabular}

It can be seen that the results obtained in the present study are quite similar with these previous results on the final yields of solid residue, total gas and tar. The small differences, in particular on the yields of gas and tar may result from the 
measurement uncertainty, the differences of biomass feedstock and of the reactor configuration.

Secondly, in the gas phase, it is found that $\mathrm{CO}$ is the main gaseous product ( 50 wt.\% of virgin biomass), followed by $\mathrm{H}_{2}$ (the molar ratio of $\mathrm{H}_{2} / \mathrm{CO}$ is between 0.35 and 0.55), $\mathrm{H}_{2} \mathrm{O}, \mathrm{CO}_{2}$ and $\mathrm{CH}_{4}$. Species $\mathrm{C}_{2} \mathrm{H}_{2}, \mathrm{C}_{2} \mathrm{H}_{4}, \mathrm{C}_{2} \mathrm{H}_{6}$ and $\mathrm{C}_{6} \mathrm{H}_{6}$ are present in much lower amounts. These results are in accordance with those observed by several earlier researchers working under similar operating conditions (Wei, $\mathrm{Xu}$ et al. 2006; Dupont, Commandré et al. 2008; Couhert, Commandré et al. 2009).

\subsubsection{Influence of the particle size}

The mass yields of solid residue, total gas, and tar corresponding to four reaction zone lengths at two temperatures are illustrated in Figure 3.

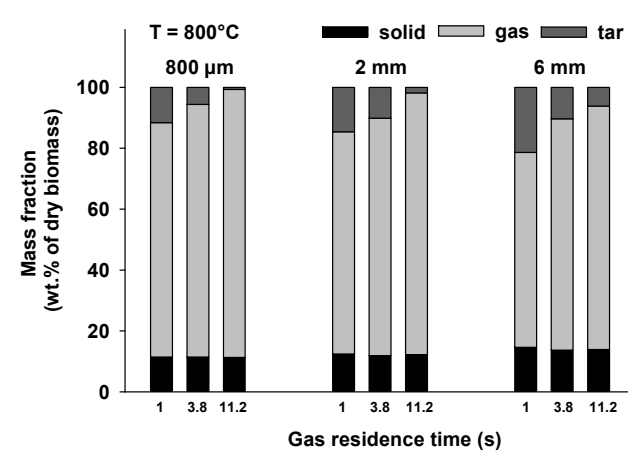

Panel (a) $\mathrm{T}=800^{\circ} \mathrm{C}$

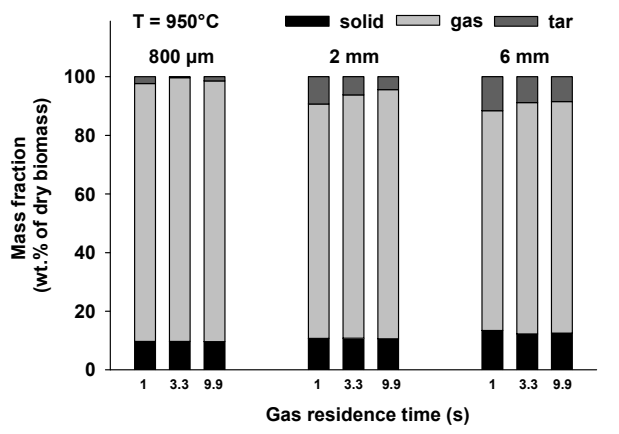

Panel (b) $\mathrm{T}=950^{\circ} \mathrm{C}$

Figure 3. Mass yield of total gas, solid residue and tar (by diff.) in the DTR

Three different pyrolysis progress levels can be observed at $800^{\circ} \mathrm{C}$ (Figure 3 (a)) for the different particle sizes:

- For the sample of $350 \mu \mathrm{m}$, the yields of solid residue, total gas, and tar almost remain constant. This indicates that the pyrolysis is already finished after a reaction zone length of $0.3 \mathrm{~m}$.

- For the sample of $500 \mu \mathrm{m}$, the yield of solid residue slightly decreases from 10 to 6 wt.\% when the reaction zone length increases from 0.3 to $0.9 \mathrm{~m}$. Meanwhile, the yield of total gas significantly increases from 63 to $83 \mathrm{wt} . \%$, and the yield of tar significantly decreases from 27 to $11 \mathrm{wt} . \%$. This indicates that the wood devolatilization is almost finished at a reaction zone length of $0.3 \mathrm{~m}$, while the cracking reactions of the primary tar produced by wood 
devolatilization are still in progress with the increase of the reaction zone length from 0.3 to $0.9 \mathrm{~m}$.

- For the samples of 700 and $800 \mu \mathrm{m}$, the yields of solid residue significantly decrease from 36 to $10 \mathrm{wt} . \%$ and from 50 to $21 \mathrm{wt} . \%$ respectively. The yields of total gas significantly increase from 42 to $71 \mathrm{wt} . \%$ and from 37 to $59 \mathrm{wt} . \%$ respectively. This indicates that in this case the wood devolatilization is still in progress in reaction zone lengths from 0.3 to $0.9 \mathrm{~m}$.

From these observations, it appears that the increase of particle size under the explored range $(350-800 \mu \mathrm{m})$ significantly decreases the apparent pyrolysis rate and therefore increases the required time for completing pyrolysis reactions.

Secondly, the influence of the particle size on the final products distribution at the end of pyrolysis can be analyzed. This analysis is performed on the results obtained at $950^{\circ} \mathrm{C}$ and at a reaction zone length of $0.9 \mathrm{~m}$ because under these conditions, the pyrolysis can be considered as finished for all the samples. From Figure 3 (b), it can be seen that with the increase of the particle size from 350 to $800 \mu \mathrm{m}$, the total solid yield slightly increases from 4 to $8 \mathrm{wt} . \%$ and the total gas yield slightly decreases from 85 to $79 \mathrm{wt} . \%$. Taking into account the experimental uncertainty, it seems that under the explored conditions, the particle size has no significant influence on the final yields of solid and gas.

It is also interesting to see whether the particle size affects the final yields of the main gaseous component (Figure 4).

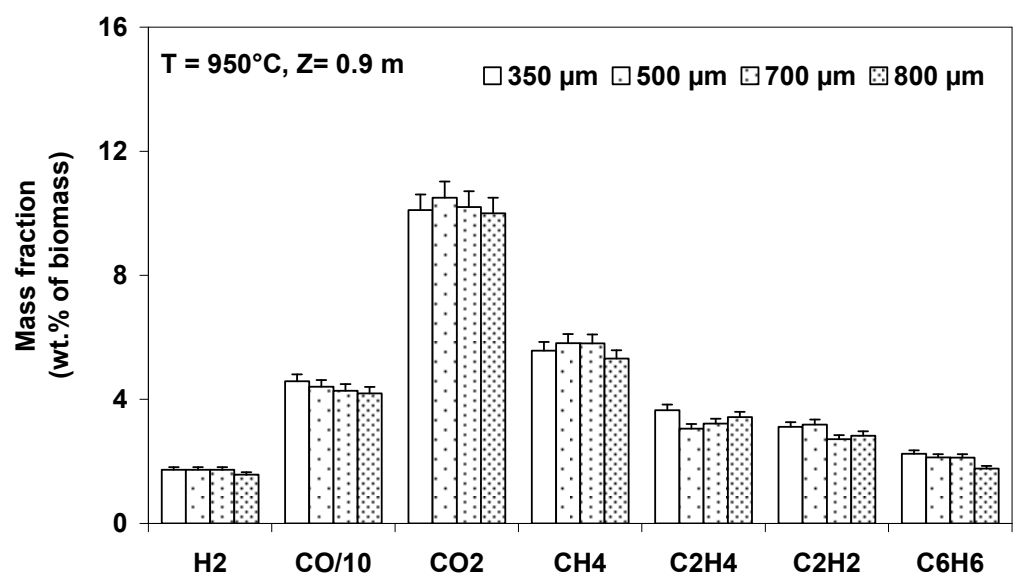

Figure 4. Yields of the main gaseous components in the DTR $\left(\mathrm{T}=950^{\circ} \mathrm{C}\right)$

These results plotted in Figure 4 reveal that the particle size does not have significant influence on the yields of gaseous components.

To sum up, the above results seem to indicate that under the explored conditions in the DTR, the increase of initial particle size from 350 to $800 \mu \mathrm{m}$ 
mainly increases the required time for completing pyrolysis, but do not significantly shift the final products distribution. Several former studies (Chan, Kelbon et al. 1985; Di Blasi 1996) concerning the influence of particle size in a higher range $(>10 \mathrm{~mm})$ showed that a larger particle size gives a higher solid yield and a low gas yield due to the fact that under the same external heat flux conditions, the change of particle size changes the temperature-history inside the particle and therefore changes the products distribution. However, in the present study, the influence of the particle size on the final products distribution is not significant, which implies that under the explored conditions, the effect of the heat transfer processes could not be effective.

\subsubsection{Influence of the reactor temperature}

From the comparison between Figure 3 (a) and (b), it can be seen on the samples of 700 and $800 \mu \mathrm{m}$ that the increase of temperature from 800 to $950^{\circ} \mathrm{C}$ logically increases the pyrolysis rate. On the contrary, it can be seen on the sample of 350 $\mu \mathrm{m}$ that the increase of temperature from 800 to $950^{\circ} \mathrm{C}$ has very little influence on the final solid/gas/tar yields.

One can furthermore investigate the influence of temperature on the final yields of the main gaseous components. Since it has been shown in the previous section that the for the sample of $350 \mu \mathrm{m}$ the pyrolysis is finished at all the studied operating conditions, the results on the sample of $350 \mu \mathrm{m}$ at 800 and $950^{\circ} \mathrm{C}$ are taken for the comparison (Figure 5).

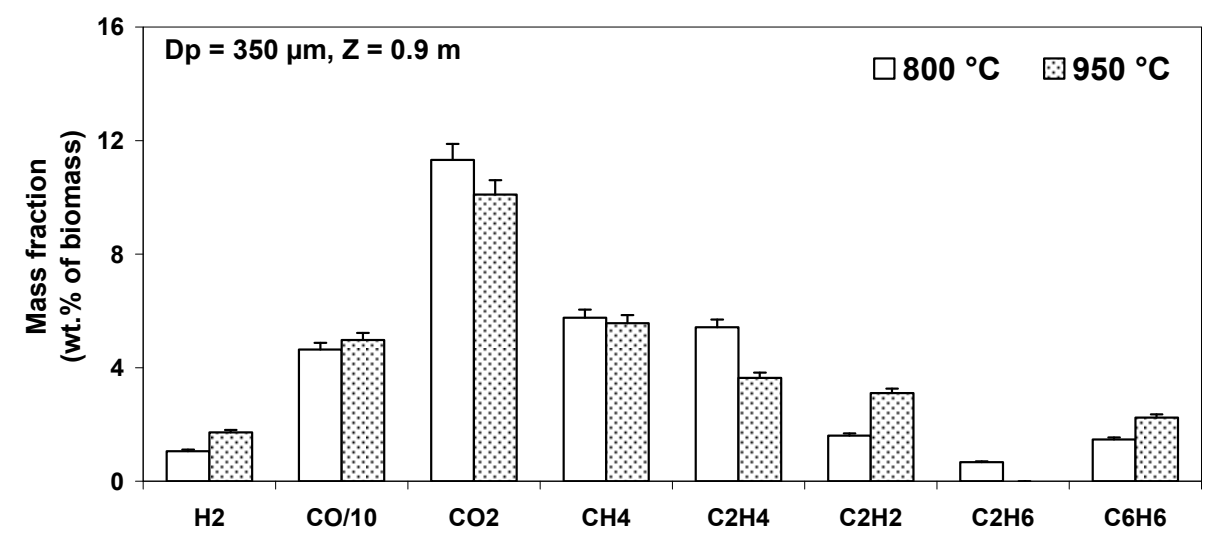

Figure 5. Influence of the temperature on the final yields of gaseous components at the end of pyrolysis in the DTR 
It can be observed that with the increase of temperature from 800 to $950^{\circ} \mathrm{C}$, the yield of $\mathrm{H}_{2}$ increases significantly (from $1 \%$ to $1.7 \mathrm{wt} \%$ of virgin wood), accompanied with the increase of $\mathrm{C}_{2} \mathrm{H}_{2}$ and $\mathrm{C}_{6} \mathrm{H}_{6}$ and the decrease of $\mathrm{C}_{2} \mathrm{H}_{4}$ and $\mathrm{C}_{2} \mathrm{H}_{6}$. Note that this trend is similar with what was observed in earlier studies (Ekstrom and Rensfelt 1980; Nunn, Howard et al. 1985; Zanzi 2001). From this observation, it may be asserted that the increase of $\mathrm{H}_{2}$ and $\mathrm{C}_{2} \mathrm{H}_{2}$ mainly comes from the cracking reactions of $\mathrm{C}_{2} \mathrm{H}_{4}, \mathrm{C}_{2} \mathrm{H}_{6}$, and tar components in the gas phase. This implies that under the explored conditions in the present study, the distribution of the main gaseous components at the end of pyrolysis is influenced by the gas phase reactions rather than the initial particle size.

\subsection{Results of experiments in HTR}

\subsubsection{Influence of the particle size}

Figure 3 reports the evolution of the yields of solid residue, total released gas, and tar versus the gas residence time for particles of different sizes at 800 and $950^{\circ} \mathrm{C}$. It should be kept in mind that due to the long solid residence time ( 3 minutes), the solid devolatilization process is finished in all cases.

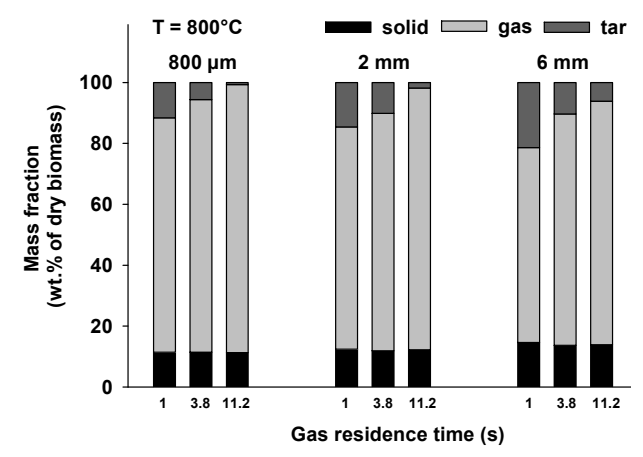

Panel (a) $\mathrm{T}=800^{\circ} \mathrm{C}$

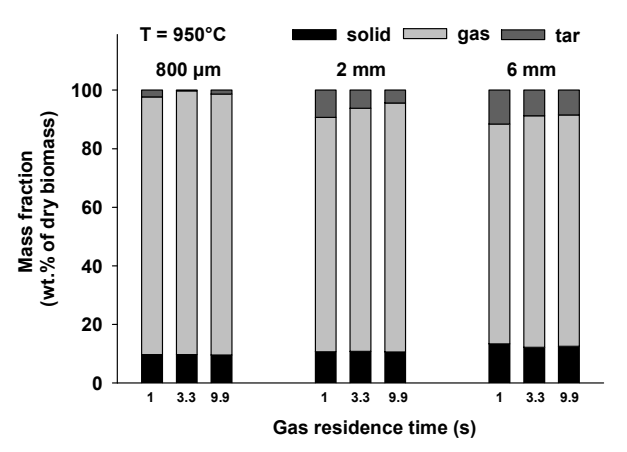

Panel (b) $\mathrm{T}=950^{\circ} \mathrm{C}$

Figure 6. Mass yield of total gas, solid residue and tar (by diff.) in the HTR

It can be observed that whatever the temperature and gas residence time, the increase of particle size from $800 \mu \mathrm{m}$ to $6 \mathrm{~mm}$ always increases the solid yield of about $2-3$ wt.\% of the initial dry wood and decreases the total gas yield of about $10 \%$. Since the solid yield is accurately measured, this indicates that under the explored conditions in the HTR, the increase of particle size increases the solid yield. 
In Figure 7, the influence of particle size on the final yields of the main gaseous components at $800^{\circ} \mathrm{C}$ is examined.

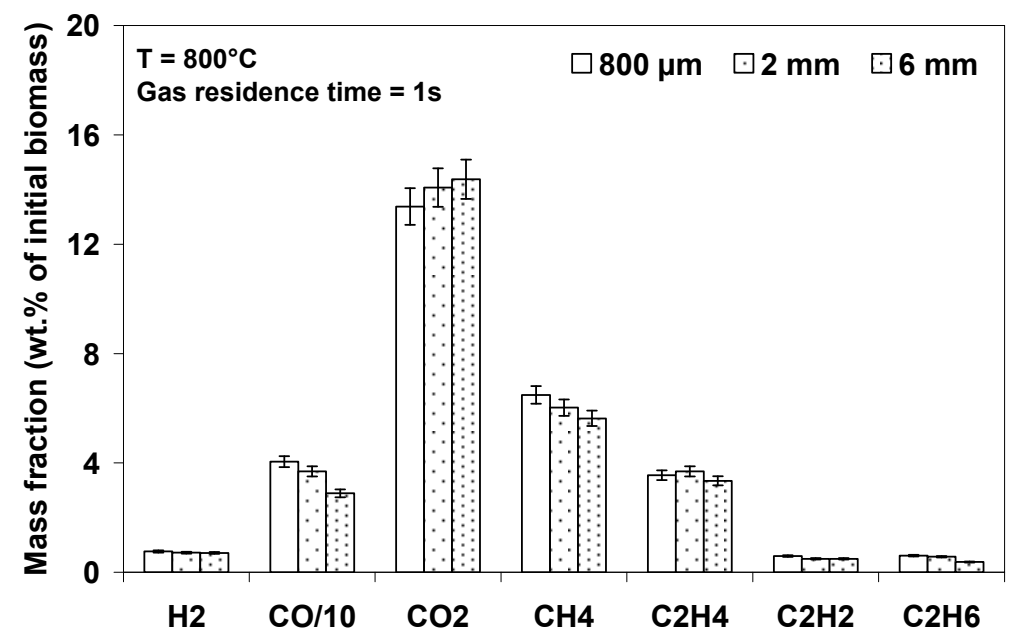

Figure 7. Influence of particle size on the final yield of the main gaseous components

From this figure, it can be seen that the decrease of the total gas yield with the increase of the particle size is mainly due to the decrease of the $\mathrm{CO}$ yield. Note that the same impact of particle size has also been observed at $950^{\circ} \mathrm{C}$.

\subsubsection{Influence of the gas residence time}

The influence of the gas residence time on the solid/total gas/tar yields can be deduced from the results shown in Figure 3. First of all, it can be observed that the increase of the gas residence time does not influence the yield of solid residue. This means that wood devolatilization behaviour is not influenced by the change of the gas velocity at the solid surface and therefore the change of mass/heat transfer conditions at solid surface. Secondly, it can be observed that at $800^{\circ} \mathrm{C}$, for all the samples, the increase of the gas residence time from 1 to $11 \mathrm{~s}$ increases the total gas yield by about 10-15 wt.\% (of dry wood). A similar evolution was observed by Zhang et al. (2007) using the same type of reactor. This trend may be due to fact that longer gas residence time favours the cracking reactions of tar components and other light hydrocarbons. Finally, it can be observed that at $950^{\circ} \mathrm{C}$, the increase of the gas residence time has almost no influence on the total gas yield for all the samples. This may be explained by the fact that at higher 
temperature, the rate of the cracking reactions increase and that as a consequence, the cracking reactions are almost finished in $1 \mathrm{~s}$ at $950^{\circ} \mathrm{C}$.

One can furthermore investigate the influence of the gas residence time on the yields of the main gaseous components. In fact, the influence of the gas residence time has been found to be the same for all the samples used in this study, hence only the results for the sample of $6 \mathrm{~mm}$ are given as an example (Figure 8).

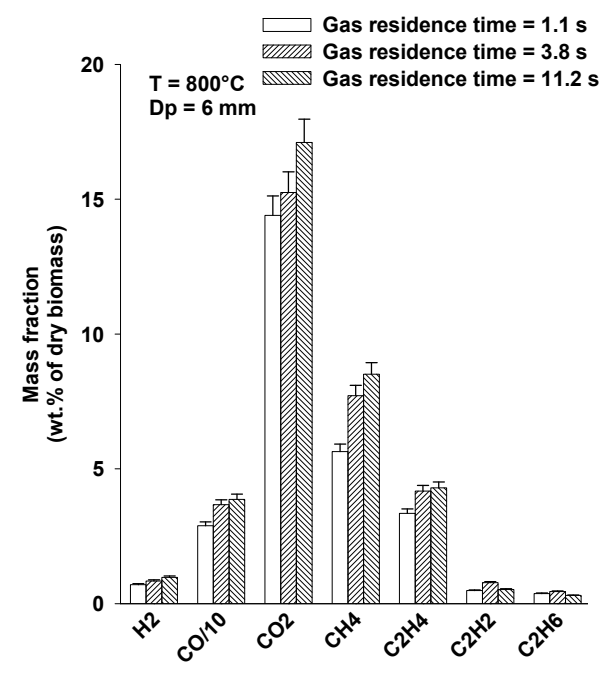

Panel (a) $\mathrm{T}=800^{\circ} \mathrm{C}$

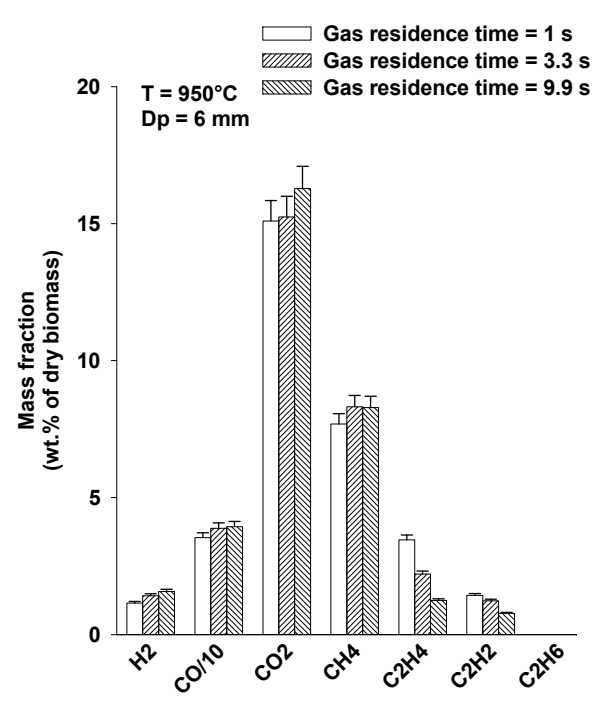

Panel (b) $\mathrm{T}=950^{\circ} \mathrm{C}$

Figure 8. Influence of the gas residence time on the yields of the main gaseous components

It can be observed that the increase of gas residence time has a significant influence on the yields of the main gaseous components: the yields of $\mathrm{H}_{2}, \mathrm{CO}$ and $\mathrm{CH}_{4}$ increase at the two temperatures; the yields of $\mathrm{C}_{2} \mathrm{H}_{2}$ and $\mathrm{C}_{2} \mathrm{H}_{4}$ increase at $800^{\circ} \mathrm{C}$ but decrease at $950^{\circ} \mathrm{C}$; a small amount of $\mathrm{C}_{2} \mathrm{H}_{6}$ is found at $800^{\circ} \mathrm{C}$ while no $\mathrm{C}_{2} \mathrm{H}_{6}$ is detected at $950^{\circ} \mathrm{C}$. These trends suggest that the gas phase reactions are still under progress under these conditions: the increase of the gas residence time favours mainly the tar cracking reactions at $800^{\circ} \mathrm{C}$ to increase the production of light hydrocarbons, while at $950^{\circ} \mathrm{C}$ it favours the not only the cracking reactions of tar components, but also those of light hydrocarbons. 


\subsubsection{Comparisons between results obtained in the DTR and in the HTR}

Since the sample of $800 \mu \mathrm{m}$ has been used for the experiments in the DTR and in the HTR, a direct comparison of the two reactors is possible. The experiments were carried out at the same temperature $\left(950^{\circ} \mathrm{C}\right)$ and for the same gas residence time (about $4 \mathrm{~s}$, corresponding to a reaction zone length of $0.9 \mathrm{~m}$ in the DTR). It is worth noticing that due to the different reactor configurations, there are two main differences between the experiments:

- In the DTR the particles could be thought as isolated and in motion, while in the HTR the particles are in contact with each other and also in contact with the sample holder. Thus, the external heat transfer conditions at particle surface in two reactors are different.

- In the DTR the solid is always in contact with the released gaseous components, while in the HTR the released gaseous components are rapidly drawn away from the particle surface.

The comparison of the yields of the main gaseous components is listed in Table 7.

Table 7. Comparison between the yields of the main gaseous components in the DTR and in the HTR

\begin{tabular}{|c|c|c|}
\hline Operating condition & \multicolumn{2}{|c|}{$\mathrm{T}=950^{\circ} \mathrm{C}$} \\
& Gas residence time $=4 \mathrm{~s}$ \\
\hline Mass yield (wt. \% of dry biomass) & DTR & HTR \\
\hline $\mathrm{H}_{2}$ & 1.7 & 1.4 \\
\hline $\mathrm{CO}$ & 48.4 & 45.5 \\
\hline $\mathrm{CO}_{2}$ & 10.1 & 14.8 \\
\hline $\mathrm{CH}_{4}$ & 5.7 & 9.1 \\
\hline $\mathrm{C}_{2} \mathrm{H}_{4}$ & 3.7 & 2.7 \\
\hline $\mathrm{C}_{2} \mathrm{H}_{2}$ & 3.1 & 1.0 \\
\hline $\mathrm{C}_{2} \mathrm{H}_{6}$ & 0.4 & 0.0 \\
\hline Total gas & 73 & 75 \\
\hline
\end{tabular}

Globally speaking, despite the differences between the two reactors, the results on the yields of the main gaseous components obtained in these two reactors are very close. When having a more detailed look at the results, it can be noticed that the yields of $\mathrm{CO}_{2}$ and $\mathrm{CH}_{4}$ are found to be higher in the HTR than in the DTR, while for the others, the yields in the DTR are a little higher than in the HTR. However, these differences remain minor. This indicates that the differences of reactor configuration and heating conditions between DTR and HTR do not play an important role in the production of the main gaseous components. Consequently, it seems reasonable to use these two reactors conjointly to study the influence of the particle size on the sample pyrolysis behaviour. 


\section{Conclusions}

The pyrolysis behaviour of beech wood particles between $350 \mu \mathrm{m}$ and $6 \mathrm{~mm}$ was investigated under representative conditions of fluidized bed gasifiers, i.e. atmospheric pressure, high external heat flux $\left(10^{5}-10^{6} \mathrm{~W} \cdot \mathrm{m}^{-2}\right)$ and high temperatures $\left(800\right.$ and $\left.950^{\circ} \mathrm{C}\right)$. A drop tube reactor (DTR) was used to study the pyrolysis of particles between 350 and $800 \mu \mathrm{m}$, and a horizontal tubular reactor (HTR) was used to complete the study with larger particles $(800 \mu \mathrm{m}-6 \mathrm{~mm})$ and to study the influence of the gas residence time (1 to $10 \mathrm{~s}$ ).

Generally speaking, under the operating conditions studied in the present work, at the end of pyrolysis, more than $80 \mathrm{wt} . \%$ of virgin wood is converted into gas and less than 13 wt.\% remains in solid. In the gas phase, $\mathrm{CO}$ is the main gaseous product ( $50 \mathrm{wt} . \%$ of virgin wood), followed by $\mathrm{H}_{2}$ (the molar ratio of $\mathrm{H}_{2} / \mathrm{CO}$ is between 0.35 to 0.55$), \mathrm{H}_{2} \mathrm{O}, \mathrm{CO}_{2}$ and $\mathrm{CH}_{4}$. Species $\mathrm{C}_{2} \mathrm{H}_{2}, \mathrm{C}_{2} \mathrm{H}_{4}, \mathrm{C}_{2} \mathrm{H}_{6}$ and $\mathrm{C}_{6} \mathrm{H}_{6}$ are present in much lower amounts, which is found in accordance with previous experimental results in similar conditions.

Under the explored conditions in the present study, the increase of the particle size significantly increases the required time for pyrolysis. However, the particle size has only a limited influence on the final products distribution of pyrolysis. Indeed, the increase of particle size from 350 to $800 \mu \mathrm{m}$ does not significantly affect the products yields at the end of pyrolysis while a little influence can be seen with the increase of the particle size from $800 \mu \mathrm{m}$ to $6 \mathrm{~mm}$, i.e. increasing the yield of solid residue by about 3 wt.\% (of dry wood) and decreasing the yield of total gas by about $10 \mathrm{wt} . \%$ (mainly $\mathrm{CO}$ yield).

The increase of temperature from 800 to $950^{\circ} \mathrm{C}$ logically increases the apparent pyrolysis rate. Moreover, the change of temperature changes the yields of the main gaseous components, i.e. higher temperature favours the cracking reactions and increasing significantly the yield of $\mathrm{H}_{2}$.

Finally, it has been shown that the final yields of the main gaseous components obtained under similar conditions in the two different reactors are very close. Thus the potential differences between the two reactors do not significantly affect the results. This confirms that it is reasonable to use them conjointly in the study. 


\section{References}

Bellais, M. (2007). Modelling of the pyrolysis of large wood particles, Royal Institute of Technology. Ph.D Thesis.

Biagini, E., C. Fantozzi, et al. (2004). "Characterization of devolatilization of secondary fuels in different conditions." Combustion Science and Technology 176: $685-703$.

Brink, D. L. and M. S. Massoudi (1978). "A Flow Reactor Technique for the Study of Wood pyrolysis.I. Experimental." Journal of Fire\&Flammability 9: 176188.

Chan, W. C. R., M. Kelbon, et al. (1985). "Modelling and experimental verification of physical and chemical processes during pyrolysis of a large biomass particle." Fuel 64: 1505-1513.

Chen, L., C. Couhert, et al. (2009). "Char/gas/tar yields and slip velocity of millimetric wood particles during high temperature fast pyrolysis - Part 2: Modelling study." In preparation.

Commandré, J.-M. (2002). Formation des oxydes d'azote lors de la combustion de cokes de pétrole dans des conditions de précalcinateur de cimenterie, Ecole des Mines d'Albi-Carmaux. Ph.D Thesis.

Couhert, C. (2007). Pyrolyse Flash à Haute Température de la Biomasse LignoCellulosique et de Ses Composés-Production de Gaz de Synthèse, Ecole des Mines de Paris. Ph.D Thesis.

Couhert, C., J.-M. Commandré, et al. (2009). "Is it possible to predict gas yields of any biomass after rapid pyrolysis at high temperature from its composition in cellulose, hemicellulose and lignin?" Fuel 88(3): 408-417.

Damköhler, G. (1936). "Einflüsse der Strömung, Diffusion und des Wärmeüberganges auf die Leistung von Reaktionsöffen." Z.Elektrochem. 42: 846.

Di Blasi, C. (1996). "Kinetic and Heat Transfer Control in the Slow and Flash Pyrolysis of Solids." Ind. Eng. Chem. Res. 35: 37-46. 
Dufour, A. (2007). Optimisation de la Production d'Hydrogène par Conversion du Méthane dans les Procédés de Pyrolyse/Gazéification de la Biomasse. Nancy, Institut National Polytechnique de Lorraine. Ph. D Thesis.

Dupont, C. (2006). Vapogazéification de la Biomasse: Contribution à l'Etude de la Phénoménologie entre 800 et $1000^{\circ} \mathrm{C}$, Université Claude Bernard -- Lyon 1. Ph.D Thesis.

Dupont, C., G. Boissonnet, et al. (2007). "Study on the Kinetic Processes of Biomass Steam Gasification." Fuel 86(1-2): 32-40.

Dupont, C., J.-M. Commandré, et al. (2008). "Biomass pyrolysis experiments in an analytical entrained flow reactor between $1073 \mathrm{~K}$ and $1273 \mathrm{~K}$." Fuel 87(7): 1155-1164.

Ekstrom, C. and E. Rensfelt (1980). Flash Pyrolysis of Biomass in Sweden. Specialists' Workshop on Fast Pyrolysis of Biomass., Copper Mountain Co.

Gronli, M. G. (1996). A theoretical and experimental study of the thermal degradation of biomass, The Norwegian University of Science and Technology.

Ph.D Thesis.

Lehto, J. (2007). "Determination of Kinetic Parameters for Finnish Milled Peat Using Drop Tube Reactor and Optical Measurement Techniques." Fuel 86: 16561663.

Li, S., S. Xu, et al. (2004). "Fast Pyrolysis of Biomass in a Free-Fall Reactor for Hydrogen-Rich Gas." Fuel Processing technology 85: 1201-1211.

Lu, H. (2006). Experimental and Modeling Investigations of Biomass Particle Combustion, Brigham Young University. Ph.D Thesis.

Nunn, T. R., J. B. Howard, et al. (1985). "Product Compositions and Kinetics in the Rapid Pyrolysis of Sweet Gum Hardwood." Industrial \& Engineering Chemistry Process Design and Development 24(3): 836-844.

Peters, B. and C. Bruch (2003). "Drying and Pyrolysis of Wood Particles: Experiments and Simulation." Journal of Analytical and Applied Pyrolysis 70: 118. 
Pyle, D. L. and C. A. Zaror (1984). "Heat Transfer and Kinetics in the Low Temperature Pyrolysis of Solids." Chemical Engineering Science 39(1): 147-158.

Simmons, G. M., M. Gentry (1986). "Particle Size Limitations due to Heat Transfer in Determining Pyrolysis Kinetic of Biomass." Journal of Analytical and Applied Pyrolysis 10: 117-127.

Van de Steene, L. (1999). Thermochimie de la Combustion à Basses Températures de Solides Pulvérisés : Application à un Charbon, Institut National Polytechnique de Toulouse. Ph.D Thesis.

Wei, L. G., S. P. Xu, et al. (2006). "Characteristics of Fast Pyrolysis of Biomass in a Free Fall Reactor." Fuel Processing Technology 87: 863-871.

Xiu, S. N., Z. H. Li, et al. (2006). "Devolatilization Characteristics of Biomass at Flash Heating Rate." Fuel 85: 664-670.

Zanzi, R. (2001). Pyrolysis of biomass: Rapid Pyrolysis at High Temperature; Slow Pyrolysis for Active Carbon Preparation, Royal Institute of Technology. Ph.D Thesis.

Zanzi, R., K. Sjöström, et al. (1996). "Rapid high-temperature pyrolysis of biomass in a free-fall reactor." Fuel 75(5): 545-550.

Zanzi, R., K. Sjöström, et al. (2002). "Rapid pyrolysis of agricultural residues at high temperature." Biomass and Bioenergy 23(5): 357-366.

Zanzi, R., K. Sjostrom, et al. (1996). "Rapid High-Temperature Pyrolysis of Biomass in a Free-Fall Reactor." Fuel 75: 545-550.

Zhang, J. L., H. Toghiani, et al. (2007). "Product Analysis and Thermodynamic Simulations from the Pyrolysis of Several Biomass Feedstocks." Energy \& Fuel 21: 2373-2385.

Zhang, Y., S. Kajitani, et al. (2006). "Peculiarities of rapid pyrolysis of biomass covering medium- and high-temperature ranges." Energy \& Fuels 20(6): 27052712.

Zhang, Y., S. Kajitani, et al. (2006). "Peculiarities of Rapid Pyrolysis of Biomass Covering Medium- and High-Temperature Ranges." Energy \& Fuels 20: 2705-2712. 